\title{
WING DIMORPHISM IN TUSCAN POPULATIONS OF RHYZOBIUS LITURA (FABRICIUS) (COLEOPTERA COCCINELLIDAE)
}

\author{
(*) Department of Agriculture, Food and Environment, University of Pisa, Via San Michele degli Scalzi, 2, 56124 Pisa, \\ Italy; e-mail: roberto.canovai@unipi.it
}

Canovai R. - Wing dimorphism in Tuscan populations of Rhyzobius litura (Fabricius) (Coleoptera Coccinellidae).

Wing polymorphism is well known among beetle families such as Carabidae, Staphylinidae, Tenebrionidae and Curculionidae, but it is relatively uncommon among Coccinellidae. Rhyzobius litura (Fabricius) is one of the Italian Coccinellidae species, with a dimorphism involving the second pair of wings which may be fully developed (macropterous) or may assume a ribbon-like structure (brachypterous). Specimens of $R$. litura collected from localities of the Tuscan Archipelago (islands of Elba, Gorgona and Pianosa, Province of Leghorn) and Tuscan hinterland (Lorenzana, San Giuliano and Ponsacco, Province of Pisa) were examined for wing dimorphism. Different sampling techniques were used: Malaise traps, pitfall traps, beating tray, collecting net and visual search. Specimens collected were either adults or larvae, these latter were reared till maturity and then examined. Results showed a remarkable homogeneity within the examined populations, which were always constantly or strongly brachypterous or macropterous. Most of the populations examined were composed of specimens which were brachypterous or with a high level of brachyptery, but the population from the island of Pianosa was entirely composed of macropterous specimens. The hypothesis that the emergence of a long-winged population could be due to geographical isolation is discussed.

KeY words: Coccinellids, wing polymorphism, sampling techniques, Tuscan Archipelago.

\section{INTRODUCTION}

The evolution of flight, enhancing the use of heterogeneous habitats, was the key innovation in the success of the class Insecta (WAGNER and LIEBHERR, 1992). Nevertheless this flight ability was secondary lost independently and repeatedly in most winged insect orders (RoOF, 1990). Among insects there are winged and strong fliers species, such as dragonflies, and nonwinged forms, such as fleas and lice (ARNETT, 1985). Between these two extremes there are dimorphic species, with some winged specimens capable of flight and others with rudimentary flight apparatus and flightless (RoOF, 1994). These dimorphic insect species may show the absence of wings (aptery) or wings too small to permit flight (brachyptery) and fully developed wings (macroptery) (Roof, 1986).

According to HAMMOND (1985) wing polymorphism is of wide and frequent occurrence among Coleoptera and such polymorphism is often expressed as a strict dimorphism (LINDROTH, 1949). Even if several species of beetles exhibit wing polymorphism, for most beetle families and most regions of the world the phenomenon of wing polymorphism is not well documented and in several cases, wingpolymorphic species were reported incorrectly to be either constantly macropterous or constantly brachypterous (HAMMOND, 1985).

Among Coccinellidae, brachyptery is relatively uncommon and apart from the subfamily Lithophilinae, where aptery is the rule, wing reduction is exhibited by species of the genus Rhyzobius and allied genera and by species of the phytophagous subfamily Epilachninae such as Subcoccinella vigintiquatuorpunctata (Linnaeus) and Cynegetis impunctata (Linnaeus) (Pope, 1977). Wingless phenotypes of Adalia bipunctata (Linnaeus), with the elytra and hind wings reduced, occur occasionally in the wild (MAJerus and KeARns, 1989; MARPLES et al., 1993).
According to BIELAWSKI (1955), the European native species Rhyzobius litura (Fabricius) and Rhyzobius chrysomeloides (Herbst) show the tendency to reduction of flight wings with only a few specimens with normally developed wings. POPE (1977) examined specimens of these species, housed in British collections and coming from the British Isles, continental Europe and Mediterranean countries. These species showed wing dimorphism with specimens that had fully developed wings (macropterous) and specimens with wings reduced to narrow, ribbon-like structures, usually reaching to about the level of the third abdominal segment (brachypterous). He noticed that the frequency of the two wing forms in R. litura varied geographically, with fewer British full-winged specimens (7\%) than specimens coming from other countries (30\%). Later HAMMOND (1985), studying six populations from different localities in southern England, found $24 \%$ of fullwinged specimens with quite different values among localities (between $0 \%$ and $80 \%$ ). These differences were attributed to environmental influences, finding a high level of macroptery where the habitat was subject to regular disturbance or in newly founded populations.

In Italy, according to RICCI (1986) only $10 \%$ of the specimens belonging to populations of $R$. litura are fullwinged.

On this basis, we chose to verify if $R$. litura populations from islands of the Tuscan Archipelago, as well as from mainland Tuscany, were characterized by wing polymorphism.

\section{MATERIAL AND METHODS}

Larvae and adults of $R$. litura were sampled from 2000 to 2012. The specimens were collected in six sampling sites 
(Fig. I), three of Tuscany's hinterland (Province of Pisa: Asciano, Lorenzana and Ponsacco) and three on the islands of the Tuscan Archipelago (Province of Leghorn: island of Gorgona, island of Pianosa and island of Elba). The studied sites, the different sampling methods used, the number of specimens of $R$. litura collected, their stage of development and the years they have been sampled are summarized in Table 1.

Malaise traps, pitfall traps and beating tray were employed for adults, collecting net for adults and larvae. Visual search was also carried out for larvae and it was particularly effective in Asciano. The latter site is characterized by traditionally-owned olive groves situated on the southern slopes of the Monti Pisani.

All the larvae were reared till maturity in controlled laboratory conditions $\left(22^{\circ} \mathrm{C} \pm 1\right)$ and then killed.

The wing structure and copulatory apparatus of each specimen were then examined. Chi-square tests (with Yates correction) were used to compare macropterous specimen proportions among populations from different localities (SPRINTHALL, 2007).

\section{RESULTS}

The results obtained are summarized in Table 2.

The adults collected in Lorenzana were captured by pitfall traps placed in two vineyards, one cultivated ( 9 specimens: 7 brachypterous and 2 macropterous) and another uncultivated (31 brachypterous specimens). The larvae were from the uncultivated vineyard and yielded brachypterous imagoes. Besides R. litura, pitfall traps collected also two other ladybird species, both normalwinged: Tytthaspis sedecimpunctata (L.) (28 specimens), a species which lives in similar habitats as $R$. litura (RICCI, 1986), and Scymnus (S.) frontalis (Fabricius) (5 specimens).

Larvae and adults were collected in Asciano (PI), larvae in 2003 (30 specimens) and 2006 (39 specimens), adults in 2006 (3 specimens) and 2008 (3 specimens).

A total of 189 specimens of $R$. litura, larvae and adults, were collected and examined: 88 were males $(46.56 \%)$ and 101 females $(53.44 \%), 148$ specimens were brachypterous (78.31\%) while 41 specimens were macropterous (21.69\%).

The most reliable results were obtained in Asciano, Lorenzana and on the islands of Gorgona and Pianosa with a lot of specimens collected. On the contrary, few specimens were collected on the island of Elba (only one brachypterous specimen was caught in 2009) and Ponsacco.

All specimens from Ponsacco, Asciano, the island of Gorgona and the island of Elba, were brachypterous, whereas all specimens from Pianosa were macropterous (Fig. II).

Only specimens from Lorenzana (larve and adults) showed both wing forms, even if with a high incidence of brachypterous individuals $(95 \%$ considering only the data of the pitfall traps, $95.74 \%$ considering all the specimens collected) (Tables 1 and 3).

The macropterous specimens were two adult males

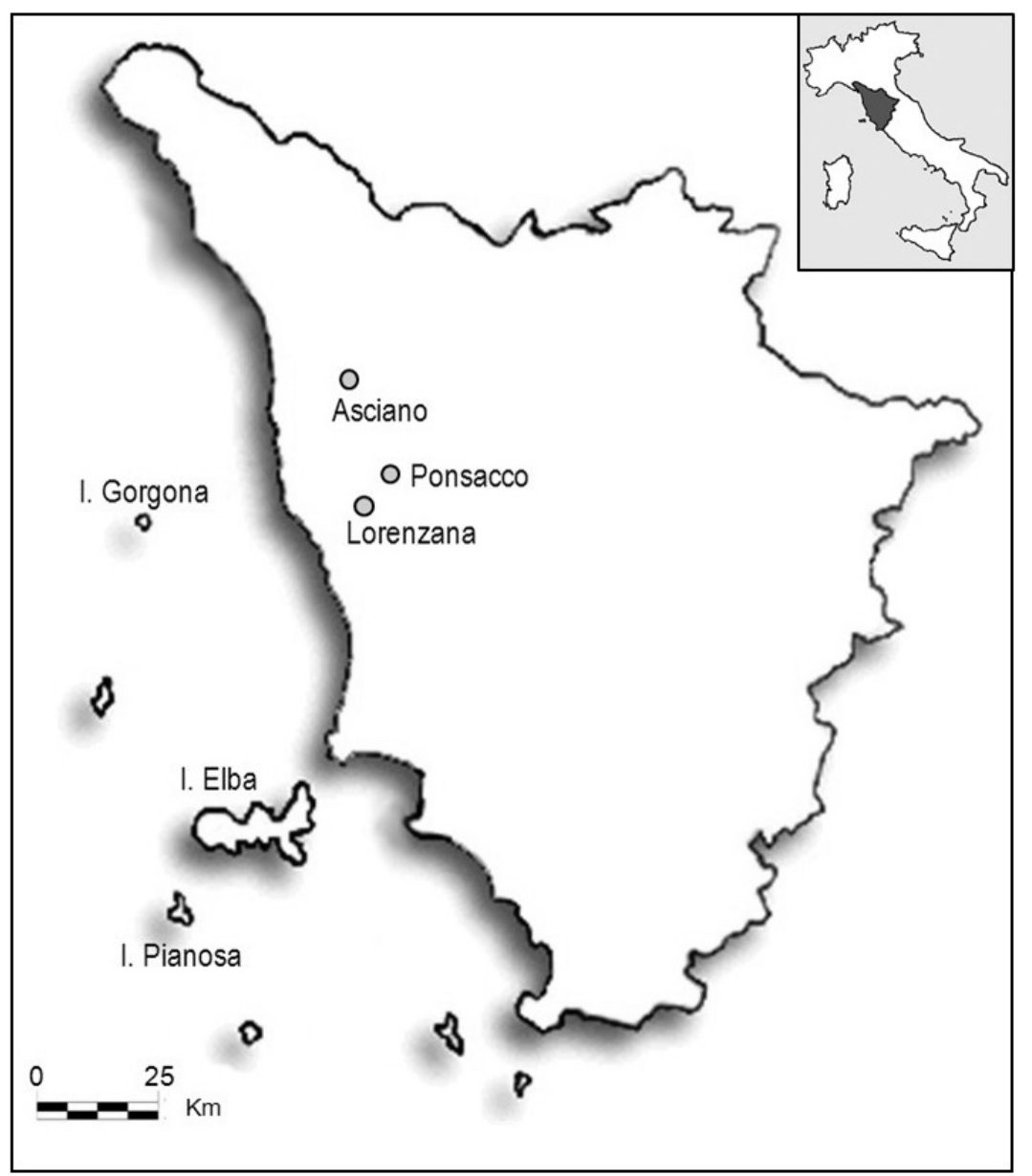

Fig. I - Rhyzobius litura - Map of the sites where specimens were collected. 
Table 1 - Rhyzobius litura - Localities of Tuscan Archipelago and coastal Tuscany where specimens of Rhyzobius litura were collected, the biotopes of the sites, the sampling techniques and the numbers of specimen collected. $\mathrm{A}=$ adults, $\mathrm{L}=$ ex larva. $*=$ specimens collected in cultivated vineyard. $* *=$ specimens collected in uncultivated vineyard.

\begin{tabular}{|c|c|c|c|c|}
\hline Sites & Biotope & Sampling techniques & Number specimens & Years \\
\hline I. Pianosa & Uncultivated soil & Two Malaise traps & $39 \mathrm{~A}$ & 2001 \\
\hline I. Gorgona & $\begin{array}{l}\text { Olive grove, uncultivated } \\
\text { soil, mediterranean bush }\end{array}$ & $\begin{array}{l}\text { One Malaise trap } \\
\text { Beating tray }\end{array}$ & $21 \mathrm{~A}$ & $\begin{array}{l}\text { Since } 1999 \text { to } 2002 \\
2000,2001 \text { and } 2002\end{array}$ \\
\hline I. Elba & Various & $\begin{array}{l}\text { Two Malaise traps } \\
\text { Beating tray }\end{array}$ & $1 \mathrm{~A}$ & $\begin{array}{c}2000,2001 \text { and } 2002 \\
1999,2001,2004,2006,2009 \text { and } 2012\end{array}$ \\
\hline Asciano & $\begin{array}{l}\text { Olive grove traditionally } \\
\text { owned }\end{array}$ & $\begin{array}{l}\text { One Malaise trap } \\
\text { Pitfall traps } \\
\text { Collecting net } \\
\text { Visual search }\end{array}$ & $\begin{array}{l}--- \\
--- \\
6 \mathrm{~A} \\
69 \mathrm{~L}\end{array}$ & $\begin{array}{l}2008 \text { and } 2009 \\
2008 \text { and } 2009 \\
2006 \text { and } 2008 \\
2003 \text { and } 2006\end{array}$ \\
\hline Lorenzana & $\begin{array}{l}\text { Cultivated vineyard. } \\
\text { Uncultivated vineyard } \\
\text { with an active ecological } \\
\text { succession in place }\end{array}$ & $\begin{array}{c}\text { Pitfall traps } \\
\text { Collecting net }\end{array}$ & $\begin{array}{c}40 \mathrm{~A} \\
\left(9^{*}, 31^{* *}\right) \\
7 \mathrm{~L}^{* *}\end{array}$ & $\begin{array}{c}2001 \text { and } 2002 \\
2006\end{array}$ \\
\hline Ponsacco & Vineyard, uncultivated soil & Collecting net & $6 \mathrm{~L}$ & 2006 \\
\hline
\end{tabular}

Table 2 - Rhyzobius litura - Brachypterous and macropterous specimens (ex larva and adults) collected from Tuscan localities. $*=$ specimens collected in cultivated vineyard. $* *=$ specimens collected in uncultivated vineyard.

\begin{tabular}{|c|c|c|c|c|c|}
\hline Sites & Specimens & Males & Females & Brachypterous & Macropterous \\
\hline I. Pianosa & 39 & 22 & 17 & - & 39 \\
\hline I. Gorgona & 21 & 7 & 14 & 21 & - \\
\hline I. Elba & 1 & 1 & - & 1 & - \\
\hline Asciano & 75 & 34 & 41 & 75 & - \\
\hline Lorenzana & $47\left(9^{*}+38^{* *}\right)$ & $22\left(5^{*}+17^{* *}\right)$ & $25\left(4^{*}+21^{* *}\right)$ & $45\left(7 *+38^{* *}\right)$ & $2 *$ \\
\hline Ponsacco & 6 & 2 & 4 & 6 & - \\
\hline Total & 189 & 88 & 101 & 148 & 41 \\
\hline Percentage & $100.00 \%$ & $46.56 \%$ & $53.44 \%$ & $78.31 \%$ & $21.69 \%$ \\
\hline
\end{tabular}

collected by pitfall traps (Tab. 3), while larvae gave rise only to brachypterous specimens (Tab. 4).

The comparison between macropterous specimens from Lorenzana and other localities showed that the number of macropterous specimens was not significantly different between Lorenzana and Asciano $\left(\chi^{2}=1.142\right.$, $\mathrm{df}=1, \mathrm{P}=$ $0.285)$ and Lorenzana and Gorgona $\left(\chi^{2}=0.033, \mathrm{df}=1, \mathrm{P}=\right.$ $0.855)$. By contrast, the number of macropterous specimens from Pianosa was significantly higher than specimens from Lorenzana $\left(\chi^{2}=74.533\right.$, df $\left.=1, \mathrm{P}<0.001\right)$. Macropterous specimens between cultivated and uncultivated vineyards in Lorenzana (Tables 3 and 4) showed statistically significant differences $\left(\chi^{2}=4.209, \mathrm{df}=1, \mathrm{P}=0.0402\right)$.

\section{DISCUSSION AND CONCLUSIONS}

The sampling technique with Malaise traps, successfully used on the island of Pianosa, avoids defects related to the operator. These traps are particularly effective against flying insects and this might have led to a selection of individuals caught on this island, where all the specimens collected were long-winged.

On the other hand, Malaise traps were active either in the olive groves near Asciano or on the islands of Gorgona and Elba and no specimen of $R$. litura was caught in these localities by Malaise traps, but specimens were collected here with beating tray, collecting net or visual search.

We believe that the use of such traps might have led to overestimate the data relative to full-winged specimens coming from the island of Pianosa. At the same time, the obtained results would exclude the presence of macropterous specimens in the areas of Asciano, Gorgona and Elba.

Pitfall traps avoid defects or mistakes by the operator. This sampling technique collects mainly species that live close to the ground and it was successfully used for $R$. litura near Lorenzana where most specimens collected were brachypterous $(95 \%)$ with only a few macropterous specimens $(5.00 \%)$.

The capture with the same pitfall traps of two ladybird species, T. sedecimpunctata and S. frontalis, both normal- 


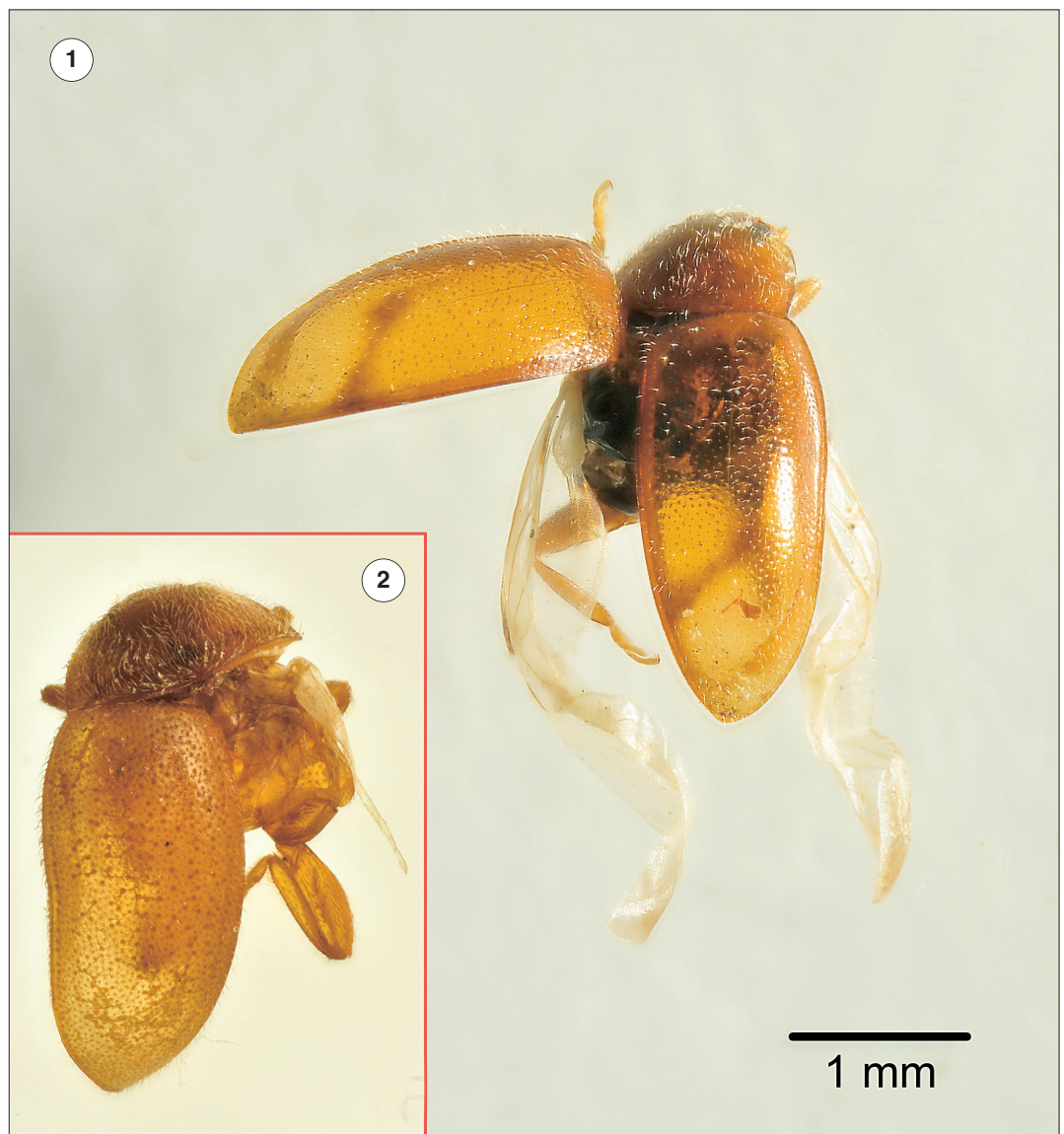

Fig. II - Rhyzobius litura - 1. Macropterous specimen from the island of Pianosa; 2. Brachypterous specimen from Asciano.

Table 3 - Rhyzobius litura - Brachypterous and macropterous adult specimens collected in Tuscan localities. $*=$ specimens collected in cultivated vineyard. $* *=$ specimens collected in uncultivated vineyard.

\begin{tabular}{|c|c|c|c|c|c|}
\hline Sites & Specimens & Males & Females & Brachypterous & Macropterous \\
\hline I. Pianosa & 39 & 22 & 17 & $\longrightarrow$ & 39 \\
\hline I. Gorgona & 21 & 7 & 14 & 21 & - \\
\hline I. Elba & 1 & 1 & - & 1 & - \\
\hline Asciano & 6 & 2 & 4 & 6 & 一 \\
\hline Lorenzana & $40\left(9^{*}+31 * *\right)$ & $21\left(5^{*}+16^{* *}\right)$ & $19\left(4 *+15^{* *}\right)$ & $38\left(7^{*}+31^{* *}\right)$ & $2 *$ \\
\hline Total & 107 & 53 & 54 & 66 & 41 \\
\hline Percentage & $100.00 \%$ & $49.53 \%$ & $50.47 \%$ & $61.68 \%$ & $38.32 \%$ \\
\hline
\end{tabular}

Table 4 - Rhyzobius litura - Brachypterous and macropterous ex larva specimens collected in Tuscan localities. ** = specimens collected in uncultivated vineyard.

\begin{tabular}{|c|c|c|c|c|c|}
\hline Sites & Specimens & Males & Females & Brachypterous & Macropterous \\
\hline Asciano & 69 & 32 & 37 & 69 & - \\
\hline Lorenzana & $7 * *$ & $1 * *$ & $6^{* *}$ & $7 * *$ & - \\
\hline Ponsacco & 6 & 2 & 4 & 6 & - \\
\hline Total & 82 & 35 & 47 & 82 & - \\
\hline Percentage & $100.00 \%$ & $42.68 \%$ & $57.32 \%$ & $100.00 \%$ & $0.00 \%$ \\
\hline
\end{tabular}

winged, shows that also good flyers may be sensitive to these traps and the terrestrial habit of the species seem rather the discriminating factor.

As regards samples in Gorgona, the common use of beating tray and collecting net for catching ladybirds (generally good flyers with the tendency to thanatosis) supplied good data due to the uniformity of results (all specimens collected on the island were adult brachypterous) confirmed by the absence of full-winged specimens of $R$. litura in Malaise traps.

Visual search is considered the sampling technique most influenced by the ability of the operator. It was used successfully against larvae of $R$. litura in Asciano. In this site, among herbaceous plants which constitute the grass 
cover of these olive groves, Coleostephus myconis (L.) Cass. (Family Asteraceae) grows luxuriantly during the spring, flowering in May-June. Heads of C. myconis are infested by Aphis fabae Scop. and Aphis spiraecola Patch. The larvae of $R$. litura frequently stay in the corollas of $C$. myconis yellow flowers actively preying on both aphid species; they are therefore well visible to an observer and easily taken. It is realistic to suppose that there are no differences in behaviour among larvae which give rise to brachypterous or macropterous specimens. Thus it is likely that the results obtained from the larvae from Asciano give a representative estimate of the proportion of brachy-versus macropterous individuals and that they are not influenced by the sampling technique used.

Overall, although these sampling techniques cannot exclude a priori any bias in the results, it seems likely that this influence, if present, is negligible and that the results can be considered reliable.

\section{WING POLYMORPHISM}

Asciano, Lorenzana, Gorgona and Pianosa, sites with a considerable number of specimens collected, showed very homogeneous populations (Tab. 2) with only brachypterous (Asciano and island of Gorgona) or macropterous specimens (island of Pianosa).

Brachypterous and macropterous specimens were found living together only in Lorenzana, with a clear preponderance of brachypterous specimens. The results obtained in Lorenzana are substantially consistent with the results obtained in Asciano and on the island of Gorgona. Therefore these populations are strongly biased towards brachypterism.

The situation is completely reversed on the island of Pianosa, where the examined population is entirely composed of macropterous specimens and it is not consistent with the results obtained in Lorenzana. This result is interesting because neither POPE (1977), nor HAMMOND (1985) or RICCI (1986) recorded populations entirely composed of macropterous specimens. The collecting technique used (Malaise traps) might have led to overestimate the results of Pianosa and the population might be composed of specimens with a high level of macroptery. Pope (1977) and Ricci (1986) focused their research broadly using material coming from several museum collections and from several localities, but HAMMOND (1985) studied in detail the incidence of dimorphism in six populations of southern England. He noticed a prevalence of brachypterous specimens at each site examined, with only one exception: 10 specimens collected on a beach showed a prevalence of macropterous $(80 \%)$, quite a different situation from Pianosa where all the 39 specimens collected were macropterous.

According to HAMMOND (1985) there is not any evidence that the incidence of macropterous specimens in populations has a geographical component. On the contrary, habitat stability seems to be the principal factor determining the relative incidence of wing dimorphism at any site. In fact a high level of macroptery may be maintained where the habitat is subject to regular disturbance, plowing for example, and a rapid change in the wing dimorphism may occur in newly founded populations. At the same time, if the vast majority of suitable habitats in a geographical area is stable, the frequency of macropterous specimens in wingdimorphic species will generally be established towards very low levels.

Our results are partially in agreement with HAMMOND (1985), in fact the situation found in the Lorenzana vineyards shows a statistically significant presence of macropterous specimens in the cultivated plot.

On the other hand, the brachypterous populations from Gorgona and Asciano and the macropterous population from Pianosa come from localities where the habitats are stable, with few anthropogenic interferences and generally not subjected to regular disturbances, but while results of Gorgona and Asciano populations are in agreement with HAMMOND (1985) the results of the Pianosa population totally disagree.

The island of Pianosa, situated $14 \mathrm{~km}$ southwest of the island of Elba, was an agricultural penal colony from 1858 until the closure of the prison in 1998, shortly before the start of the surveys we carried out. Since then, the only changes that have occurred are due to a process of natural succession. A favourable situation for brachypterous specimens according to HAMMOND (1985), but, on the contrary, the population we examined was completely composed of macropterous specimens.

HAMMOND (1985) hypothesizes that a uniformly low incidence of macroptery characteristics of British populations may be due to endogenous and climatic factors as well as models of land use. I suppose that geographical isolation, the small size of the island of Pianosa, its relative proximity to the island of Elba and the proximity of this latter to the continent $(10 \mathrm{~km})$ may have played an important role in maintaining a high level of macroptery on the island of Pianosa. These factors, even reducing the genetic exchange among sites, are not insurmountable obstacles to the flyers thus macropterous specimens could have benefited.

In this regard, it would be very interesting to obtain and rear larvae of $R$. litura from the island of Pianosa, a fact that would have allowed a better understanding of the role of rearing conditions in the development of wing dimorphism. Unfortunately, it was not possible to obtain and breed larvae of $R$. litura from this island.

\section{ACKNOWLEDGEMENTS}

I wish to thank Prof. Sebastiano Barbagallo for the determination of aphids caught on C. myconis. I would also like to thank Dr. Valeria Trivellone, who provided me with the material captured with pitfall traps in Lorenzana (PI) and who helped me in breeding the larvae of $R$. litura. I wish also to thank Dr. Angelo Canale for his valuable advice and for the critical revision of the manuscript.

\section{REFERENCES}

ARnetT R.H., 1985 - American insects. Van Nostrand Reinhold, New York, 850 pp.

BIELAWSKI R., 1955 - Morphological and systematical studies on Polish species of the Genus Rhyzobius Stephens, 1831 (Coleoptera Coccinellidae) - Annales Zoologici, Warszawa, 16 (4): 29-50.

HAMMOND P.M., 1985 - Dimorphism of wings, wing-folding and wing-toiletry devices in the ladybird, Rhyzobius litura (F.) (Coleoptera: Coccinellidae) with a discussion of inter-population variation in this and other wingdimorphic beetle species - Biol. J. Linn. Soc., 24: 15-33.

Lindroth C.H., 1949 - Die fennoskandischen Carabidae. Eine tiergoegraphische Studie. III. Allgemeiner Teil. Zugleich eine biographische Prinzipdiskussion Goteborgs Kungliga Vetenskaps- och VitterhetsSamhälles handlingar. Serien B, 4 (3): 1-911. 
Majerus M.E.N., Kearns P.W., 1989 - Ladybirds. Naturalists' Handbooks, 10 - Richmond Publishing Company, Slough. 103 pp.

Marples N.M., De Jong P.W., Ottenheim N.M., Verhoog M.D., BRAKEFIELD P.M., 1993 - The inheritance of a wingless character in the 2-spot ladybird (Adalia bipunctata) - Entomol. Exp. Appl., 69: 69-73.

Pope R.D., 1977 - Brachyptery and wing-polymorphism among the Coccinellidae (Coleoptera) - Syst. Entomol., 2: 59-66.

RICCI C., 1986 - Habitat distribution and migration to hibernation sites of Tytthaspis sedecimpunctata and Rhyzobius litura in central Italy - In: Ecology of
Aphidophaga, I. Hodek (ed.). Academia, Prague and W. Junk, Dordrecht, pp. 211-216.

Roof D.A., 1986 - The evolution of wing dimorphism in insects - Evolution, 40 (5): 1009-1020.

Roof D.A., 1990 - The evolution of flightlessness in insects - Ecol. Monogr., 60 (4): 389-421

Roof D.A., 1994 - Habitat persistence and the evolution of wing dimorphism in insects - Am. Nat., 144 (5): 772-798.

SPRINTHALL R.C., $2007-$ Basic statistical analysis. $\left(8^{\text {th }}\right.$ edition) - Allyn \& Bacon Inc., 658 pp.

WAGNER D.L., LIEBHERR J.K., 1992 - Flightlessness in insects. - Trends Ecol. Evol., 7 (7): 216-220. 